\title{
Genitive focus in Supyire
}

\author{
Robert Carlson
}

SIL \& NEGST

\begin{abstract}
Supyire has two distinct genitive constructions, one consisting of juxtaposed nouns, and the other marked with a particle. This study demonstrates that the marked genitive correlates significantly in natural discourse with contrastive focus as operationally defined in Myhill and Xing (1996). The method used avoids the vicious circularity of many discourse-based studies of focus. Contrastive focus, rather than being "coded", is a pragmatic construal which is dependent on other elements in the communicative context. This construal is only one of the possible construals of the marked genitive (contra Carlson 1994). In this it is not unlike other so-called "contrastive focus" constructions noted in the literature, such as contrastive stress in English.
\end{abstract}

\section{Unmarked and marked genitives in Supyire}

Supyire has two genitive constructions, one marked with a genitive particle, the other unmarked. Carlson (1994) devoted a single paragraph to the marked genitive:

"Constrastive focus on a genitive (possessor) noun phrase is indicated by placing a genitive particle $u$ between the genitive and the head noun. This particle has weak mid tone, and behaves tonally as if it were a possessed noun, becoming high after a mid tone, and low-weak mid after a low tone. It is obviously related to the independent possessive pronoun root wu-. The head noun following the particle is completely unaffected tonally." (Carlson 1994: 591)

Although this information is basically correct (though the genitive particle is now written wu in the orthography, and I would now label what I then called the "independent possessive pronoun" as possessum pronoun), the functional claim ("contrastive focus") was unsubstantiated beyond the furnishing of two 
examples which follow the above paragraph in Carlson (1994). It is the purpose of this paper to both justify and modify that claim.

Genitives in Supyire, whether marked or unmarked, have the obligatory order POSSESSOR - POSSESSUM.

There is no genitive case marking of nouns, and there are no genitive forms of pronouns. In the ordinary genitive the possessor and possessum NPs are merely juxtaposed. The possessum, however, in many cases undergoes a tonal change. As noted in the paragraph quoted above, the genitive particle also undergoes these changes, but the following possessum is unaffected tonally. Compare the following examples: in each ordinary genitive (the (a) examples) the possessum undergoes a tonal change, whereas in each wu-marked genitive (the (b) examples) the possessum has its base tone.

(1) possessum weak mid tone becomes high after mid tone possessor
a. mu túni ORDINARY
you father
'your father'
b. mu wú tû̀i
you FOC father
'YOUR father'
MARKED

(2) possessor ends in floating weak mid tone ${ }^{1}$
a. mì túni
ORDINARY
I father
'my father'
I FOC father
'MY father'
b. mì̀ wú tùni

(3) possessum weak mid becomes low after a low possessor
a. Wà $m \grave{\varepsilon} \grave{\varepsilon}$
INDEF voice.G3S
'one's voice'
ORDINARY
b. Wà wù meE
INDEF FOC voice.G3s
'ONE'S voice'

\footnotetext{
The second, weak mid, tone of mì floats and then disappears after causing a following weak mid to become high. The sequence $\mathrm{L}$ wM wM thus becomes $\mathrm{L} \mathrm{H}$.
} 
(4) possessor ends in a floating low tone ${ }^{2}$
a. jìjé jwùmpé
ORDINARY
these words
'the words of these'
b. jijé wù jwumpé MARKED
these FOC words
'the words of THESE'

(5) possessum low becomes mid after a mid tone possessor
a. mu pkuuní
ORDINARY
you chicken
'your chicken'
b. mu wú ìkùùni
MARKED
you FOC chicken
'YOUR chicken'

The wu-marked genitive in Supyire is not only marked in a morphological sense, but it is also marked in a discourse sense. In the coded part of the text database used for this study ${ }^{3}$, of the total of 2,738 genitive constructions, only 135 $(=4.7 \%)$ are $w u$-genitives.

As noted in the quote from Carlson (1994) above, the genitive particle wu is obviously related to the pronominal possessum form wu-, its probable historical source. ${ }^{4}$ The pronominal possessum, as its name implies, is obligatorily possessed. It agrees in gender/noun class with its "antecedent”. I put "antecedent" in quotes because, of course, the referents of the possessum pronoun and its "antecedent" are not ordinarily the same. The possessum pronoun indicates another referent of the same category as the "antecedent", as in the following example:

2 All demonstrative pronouns and all definite noun suffixes end in a floating low tone. This floating $\mathrm{L}$ docks onto the following word if it can.

3 The total database currently numbers 45,560 clauses. Of these around 20,000 have been grammatically coded. Many examples of $w u$-marked genitives from the uncoded part of the database have been used for this study, but the statistics quoted here are based on the coded part.

4 It is easy to see how a possessum pronoun of this type, meaning, roughly, "another of the same category as a referent already mentioned or evoked in the context" could be reinterpreted as a possessor focus marker. The referent of the possessum pronoun necessarily forms a set with its "antecedent" (see below for "antecedent", and section 2 for the role of sets in the construal of contrastive focus). Its possessor will thus also form a set with any possessor of the "antecedent", and the stage is then set for a contrastive construal. I assume that originally the possessum noun in a wu genitive was an appositive of the wu possessum pronoun. With reanalysis, the noun class marking on the wu pronoun would be completely redundant and be dropped. 
(6) mì̀ túni nà mu wúni

I father and you POSS.DEF

'my father and yours'

Ordinarily this would be understood as referring to two different fathers. Since pronominal possessa will appear in many examples below, the forms are given in Table 1 for reference.

Table 1: Forms of the possessum pronoun

\begin{tabular}{|c|c|l|l|l|l|l|}
\hline \multirow{2}{*}{ GENDER } & \multicolumn{2}{|c|}{ SINGULAR } & \multicolumn{2}{c|}{ PLURAL } & \multicolumn{2}{c|}{ NON-COUNT } \\
\cline { 2 - 7 } & INDEFINITE & DEFINITE & INDEFINITE & DEFINITE & INDEFINITE & DEFINITE \\
\hline $\mathbf{1}$ & $u$ & wūí & wúu & wúubíi & & \\
\hline $\mathbf{2}$ & wogo & wogé & wuyo & wuyí & & \\
\hline $\mathbf{3}$ & wuu & wuuní & wógii & wógigíí & & \\
\hline $\mathbf{4}$ & & & & & woro & wooré \\
\hline $\mathbf{5}$ & & & & & wumo & wumpé \\
\hline
\end{tabular}

\section{Operationalizing contrastive focus}

Lambrecht (1994) shows that focus stress in English, although it has often been claimed to encode contrastive focus, in fact is by no means confined to cases which can be shown to be "contrastive" on the definitions of Halliday (1967: 206 "contrary to some predicted or stated alternative") or Chafe (1976). Lambrecht suggests that contrast should be treated not as a grammatical category, but as a generalized conversational implicature. However, given the relatively strong intuitions that numerous linguists have noted concerning the interpretation of contrastive stress, and given the fact that a contrastive interpretation is very often one of the available interpretations in the made-up examples which form the bulk of Lambrecht's data, it would be interesting to see from actual discourse data ${ }^{5}$ how often there is a "stated alternative" in the discourse context of focus stress examples. This of course raises the methodological question of how to actually recognize, in a replicable way, an instance of contrast in a text.

Myhill and Xing (1996) set out to provide an answer to this methodological question, and apply it to Biblical Hebrew and Chinese discourse data. For reasons of space they look only at cases of fronted direct objects in the two languages, but they are able to provide evidence that (i) fronting of objects does indeed correlate significantly with contrast, using their operational definition of contrast, and (ii) a significant number of fronted objects do not have anything to do with contrast as so defined. The interest of Myhill and

5 That is, what Lambrecht calls "attested examples." 
Xing's study is that by operationalizing the notion of contrast to overtly observable phenomena in a text, they escape from methodological circularity. The danger of such circularity is particularly high in the case of wu-marked genitives in Supyire. It is all too easy to fall into the following type of "analytical" practice: "Hypothesis: $w u$ marks contrastive focus on the possessor NP in a genitive construction. Here is a wu marked genitive. Let me see, what is the contrast in this example?" Only an explicit and objective definition can guard against this type of circularity.

Basically, Myhill and Xing look at "stated alternatives" (and in a very restricted way at implicit alternatives, corresponding roughly to Halliday's "predicted alternatives") and are able to say what proportion of object fronting is covered by these cases. The notion of alternative implies a set relation between the alternatives. ${ }^{6}$ Operationalizing the notion of set is difficult. In this study I have used Myhill and Xing's list of types of groupings that may be considered a set (1996: 310-311):

(7) a. Complementary: Any pair of elements which are represented as complementary parts of a whole constitute a set...

b. Organizational: A group of people and things which are in the same 'social organization' constitutes a set. As types of organization, we counted families, companies, military units, etc. Possessions are counted as being part of a set with their owners...

c. Proximate: A group of people who are at the moment physically together, as in a conversation or on a trip, constitute a set...

d. Hierarchical: Specific individuals who are at the same level of a larger set of individuals constitute a set. This includes members of a family of the same generation, people at the same rank in a company, etc....

e. Rhetorical: Entities or concepts which are habitually grouped together in terms of activities or proverbs/slogans by a particular culture constitute a set for that culture...

f. Conjoined: A set may be constituted by explicitly conjoining the NPs involved... The entities referred to by the conjoined NPs then constitute a set in the discourse and presumably remain as a set for some time.

g. Analogical: Any pair of elements which have a parallel relationship with members of a set (e.g. the names of brothers, the parents of a husband and wife) also constitute a set. For example, in We will give our daughters to you, and we will take your daughters for ourselves, the speaker and the listener constitute a set (type c), and therefore their daughters also constitute a set.

6 Cf. Chafe's (1976) requirement for contrast that there be a set of possible candidates for the role that is being contrasted. 
Myhill and Xing propose two operational definitions that cover the cases that have been called contrastive in the literature. They call the two types "list" and "contrast" (1996: 306ff). In the "list" type, there are two NPs in their respective clauses which are elements of a set as defined above, while the verbs and other information in the clauses is essentially the same. For the "contrast" type, which approximates Chafe's “double contrast”, there are two subtypes. In one (called "verbal contrast"), the verbs in the two clauses are opposite, either because one is negated, or because they are antonyms of some sort. In "non-verbal contrast", on the other hand, there is a further pair of NPs, one in each clause, which are elements of a set as defined above.

Adopting Myhill and Xing's method to genitive constructions in Supyire, I will say that a genitive possessor is clearly contrastive if in the immediate context (not more than 6 clauses away) there is (i) another NP such that the genitive possessor and this other NP are elements of a set as defined above, and (ii) this $\mathrm{NP}$ is also either explicitly or by implication the possessor of a possessum such that the possessa of the two genitive constructions (that is, the wu-marked genitive and the one with which it contrasts) are elements of a set as defined above. If all other elements in the two clauses are the same, then the example approximates what Myhill and Xing call the "list" function. If there are further contrasting elements in the two clauses, the example is similar to Myhill and Xing's "contrast" function. There are in turn two subtypes of additional contrastive elements, (i) antonymous possessa in the two genitives, and (ii) predicates with opposite meaning (either due to negation of one of them, or use of antonymous verbs or adjectives). In some cases, the contrasting predicate is not explicit but must be inferred.

In this study I look only at wu-marked genitives. In further research, I intend to look at both ordinary genitives and genitives with pronominal possessa. Of the $214 w u$-marked genitives in the corpus, $113(=52.8 \%)$ may be identified as contrastive by the above definitions. Of these, $56(=26.2 \%$ of the total) are explicitly constrasted with another genitive in the context. This second genitive may or may not be marked itself with $w u$. Those examples approximating the "list function" of Myhill and Xing number $24(=11.2 \%$ of total). These will be treated in section 3 below. All the others $(\mathrm{N}=89=41.6 \%$ of total) have additional contrastive elements in the context. These will be discussed in sections 4 (those with explicit contrasting genitives) and 5 (those with implied contrasting possessa). The remaining 101 examples, which cannot be shown to be contrastive by the definitions above, will be treated in section 6 .

\section{Constrastive possessors in "listed" genitives}


The following examples illustrate constrast between possessors that are merely listed. If the possessa are distinguished only by their possessors, they may be coded with possessum pronouns:

(8) Lenjyaàyi taanna-pkânni: pi màha bànnibíi le, crossbeams line.up-manner they HAB transverse-beams put 'The way the crossbeams are lined up: they install the transverse beams,
ninké wù bànnà-ní
nà canja cwumo wú-ni

middle FOC transverse.beam-DEF.G1s and day falling POSS-DEF.G1s

when THE MIDDLE transverse beam and THE WESTERN one

nà canja foromo wú-ni kà pìyé shó, and day coming.out POSS-DEF.G1s COND themselves take and THE EASTERN one have connected with each other,

pi màha ná à j’̀kèrèmè wù-yí yà wì̀. they HAB afterwards SCN side POSS-DEF.G2P INDEF.G2P look.at they choose (lit. look at) some of the side ones (i.e. side crossbeams).'

In the following example, the possessa set is sums of money given on a particular occasion. The possessor set is those who gave the sums in question. The particle yòo has as one of its functions the marking of items in a set, and is therefore glossed LIST.

(9) Ká Bùgùdogo-ní sì jì-cyà. and Bugudogo-DEF.G1S NARR INTR $^{7}$-seek

'Then the Bugudogo was fetched.

Miì bíduuru-pí yòo, Zùmanìwú daashíi kánkúrú-ni

I 50-DEF.G1s LIST ZumaniFOC 5.franc.piece five-DEF.G1s My $250^{8}$ francs, ZUMANI's 25 francs

u à cya Bàba á ge, maá úrú kán $u$ à, he PERF seek Baba from REL and.NARR it give him to which he had got from Baba, [we] gave it to him (= to the Bugudogo),

7 The intransitive prefix occurs only after certain tense-aspect auxiliaries (among them the narrative auxiliary, as here) and only when the verb begins with a voiceless plosive.

8 Money is counted using the basic unit of the smallest coin, 5 francs. Thus 50 (units of 5 francs) equals 250 francs, and five (units of five francs) equals 25 francs. 
lù-Wu- $\eta^{\prime}$ â, maá yí jwú u a si ná ú é. water-pour-DEF.G1s to and.NARR it say he SBJCV.IMPFV go with it with to the libation-offerer, and said he should take it away.'

\section{Additional contrastive elements in the context}

In a further 32 examples, there is additional contextual support for a contrastive interpretation. In some cases this is merely negation: one of the contrasted genitives is in a clause with a negated predicate whereas the other one is not. The following two examples come from a tale in which Coucal and God have a contest to see whose voice will carry the farthest. In (10) the same verb is used in the two clauses (one of which is negated). The situation in (11) is more complicated: in the first clause the contrasted genitive is the subject, and the predicate is "heard God's", while in the second clause the contrasted genitive is a goal postpositional phrase in a negative clause "Coucal's didn't arrive". The song being heard by the addressee can be counted as synonymous with the song arriving at the addressee. This example is thus similar to (10) in that one of the synonymous predicates is negated.

(10) Kà Dúdugo rí mípá lí tá uru wù mec-ní jye a jà and Coucal NARR come it find he FOC voice-DEF.G3S NEG PERF be.able 'Then Coucal realized that HIS voice had not been able to

$a$
$a$$\quad u$ wú cwồni na mé, Kile wùù-ní $\quad d$ ' ‘a $\quad$ 'no ... SCN arrive he FOC wife.DEF.G1s at NEG God POSS-DEF.G3S ADV PERF arrive reach his wife, whereas GoD's had reached ...'

(11) Kà Kile wì cwô-ni dì Kile wù-yí lògò, and God FOC wife-DEF.G1s NARR God POSS-DEF.G2P hear 'GoD's wife heard God's [song],

Dúdugo wú-yi jye à no mé, uru wù cwô-ni na mé. Coucal POSS-DEF.G2P NEG PERF arrive NEG he FOC wife-DEF.G1s at NEG Coucal's [song] didn't reach, didn't reach $\underline{\text { HIS wife.' }}$

The additional contrast may stem from the use of antonyms. The following example, a proverb, has antonymic possessa (good deed vs. bad deed):

(12) Wà wù ka-cènnè

INDEF FOC deed-good.G3s màha mpyi wà wù ka-pii.

HAB be INDEF FOC deed-bad.G3S 
The antonyms may be elsewhere in the context. In the following example, from a discourse on how to weave, the verbs of which the possessa are subjects are antonyms (go down vs. go up):

(13) Mu ahá j̀kétoogé tànhà, kuru ndiribíi-ni màha ntìgè, you COND this foot.DEF.G2s put.down it.G2s pedal.DEF.G3S HAB go.down 'When you lower this foot, its pedal goes down,

sì̀zi-ク刀 ásì múgó, mu arì kàzo-ní wà. thread-DEF.G1s HAB open you HAB shuttle-DEF.G3s throw the threads open and you throw the shuttle.

'Tké toogé sânnke, kuru wù ndiribíi-ni màha dugo, this foot.DEF.G2s other it.G2s FOC pedal.DEF.G3S HAB go.up This other foot, ITS pedal goes up

$\begin{array}{lll}\text { sì̀zi-ク’ } & \text { árì } & \text { ǹtò... } \\ \text { thread-DEF.G1s } \quad \text { HAB } & \text { close } \\ \text { and the threads close... } & \end{array}$

The following example has both antonymous verbs (refuse to take vs. take) and antonymous adjectives (good/clean vs. dirty). Note that there is a double $w u$, and both sets of possessors are contrasted:

(14) $P i \quad$ a cyì wùu mìií nincenm-pií wù yaa-yí nijncen-yí they PERF refuse we these good-DEF.G1P FOC things-DEF.G2P good-DEF.G2P 'Have they refused to take and drink the water of THE CLEAN THINGS of US GOOD

wù lwo-hé shwo-mbya-ga, sí ǵkwó yìi mìpí wù FOC water-DEF.G2s take-drink-G2s SBJCV finish you these FOC PEOPLE, in order to take and drink that of THE DIRTY LITTLE CALABASH

$\begin{array}{llll}\begin{array}{l}\text { cee-pwoho-ré } \\ \text { calabash-dirty-DIM }\end{array} & \text { wò-gé } & \text { shwo mìyà la? } \\ \text { of YOU here?' } & & \text { take drink QUES }\end{array}$

Fully sixteen examples show some combination of negation and antonyms. Following, by way of illustration, is a complicated but not atypical example. The possessors are contrasted as expected (today vs. tomorrow). There is a further contrast between the possessa (few vs. many fish) which is distributed differently in the two clauses: a negated verb ('not be many') in the first clause 
contrasts with an adjective modifying the possessum in the second clause ('many'). There is a further constrastive set in the context ('me' vs. 'you') which contributes to make a highly contrastive example.

(15) $A$, nínjáà wu fya-ngú-re

nàha à nyaha mé. ah today FOC fish-small.and.bad.quality-DEF.G4 NEG.here PERF be.many NEG 'Ah, TODAY's miserable small fish are not many.

$\begin{array}{llll}\text { Mu nínjáà wòò-ré } & \text { yaha } & \text { mìi } & \text { á, } \\ \text { you today POSS-DEF.G4 } & \begin{array}{l}\text { leave } \\ \text { me }\end{array} & \text { to } \\ \text { You should let me have today’s, } & & \end{array}$

nùmpanna wóó-re ninyaha-ré, wùu ú mípá tíré kán mu á. tomorrow POSS-DEF.G4 many-DEF.G4 we SBJCV come them give you to TOMORROW's numerous ones, we will give them to you.'

Besides negation and antonyms, one further type of contextual reinforcement of contrast is the use of the overt comparative construction. In the following example, from a conversation about two balafons, there are two pairs of contrasted genitive constructions, each in a comparative clause:

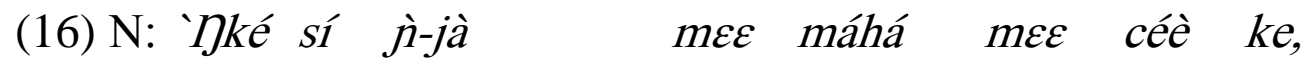 this FUT FP-be.able song every song sing REL 'Whatever song this one can play, j̣ké màha lire cè̀. Aan. this $\mathrm{HAB}$ it sing yes this [other] one can play. Yes.

A: Mè̀े wà wù ̀̀kjò̀n-g' a tààn wà wò-gò nà la? but INDEF FOC throat-DEF.G2S PERF be.sweet INDEF POSS-G2S on QUES But is the sound of ONE more pleasant than that of THE OTHER?

$\mathrm{N}:$ Wà wù j̀jkj̀òn-g' $\quad$ a pè̀ wà wò-gò nà ... INDEF FOC throat-DEF.G2S PERF be.big INDEF POSS-G2s on The sound of ONE is louder than that of THE OTHER...'

\section{Contrast without an explicit second genitive construction}

As noted above, a wu-marked genitive possessor may be contrasted with another member of its set which is mentioned explicitly in the context, but which is not the possessor in a second genitive construction. In these cases, it is clear that the 
"missing" possessum, which is of course evoked by the explicit possessum, is implicit in the conceptualization of the scene. In the following example, 'another snake' in line 4 is contrasted with 'the python' which is the possessor of the wugenitive in the final line. The implicit member of the possessum set 'poison (of snakes)' is of course implied by the bite of the second snake in line 4 .
(17) Fyì-ni
kà mu no,
python-DEF.G1s CONDyou bite
'If the python bites you,

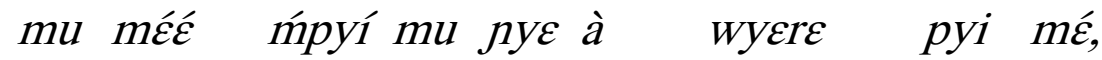
you even.if be you NEG PERF medicine do NEG
even if you don't treat it,

yafyîn pye na mu táà me.

nothing NEG PROG you get.IMPFV NEG

nothing happens to you.

\section{Lire kàntugo, wwò-ni wàbérè kà mu no, that behind snake-DEF.G1s another COND you bite Later on, if another snake bites you}

kà mu ú wyere pyi uru wwò-ni tà-non-ké na, and you NARR medicine do that snake-DEF.G1s LOC-bite-DEF.G2s on and you treat that snake's bite,

$\begin{array}{lll}\text { fyì- } \eta \mathbf{i} \quad \text { màha } & m u & \text { bó. } \\ \text { python-DEF.G1s HAB } & \text { you } & \text { kill } \\ \text { the python kills you. }\end{array}$

Nàhá ná $y \varepsilon, \quad u \quad$ màha jwo,
what on QUES he HAB say
Why? Because he says,

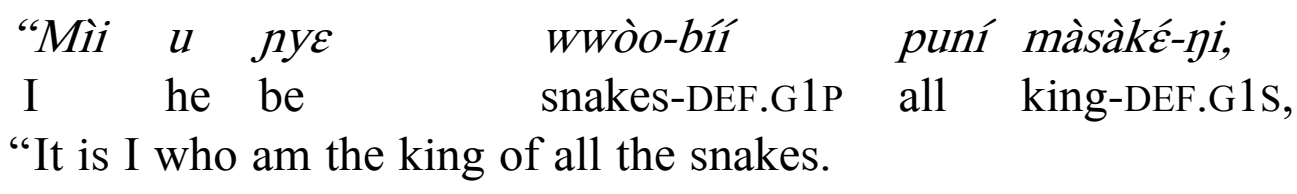

$\begin{array}{llll}\text { ká mìi } & 1 & m u & n o, \\ \text { and I } & \text { NARR } & \text { you } & \text { bite } \\ \text { I bit you, } & & & \end{array}$


mu jye à wyere pyi mé.

you NEG PERF medicine do NEG

but you didn't treat the bite.

Mì̀ bílí-ni wà à pà mu no, I slave-DEF.G1s INDEF PERF come you bite Then one of my slaves came and bit you,

kà mu ú úrú wyéré pyí, and you NARR it medicine do and you treated it.

mu à Wurugo."

you PERFdo. wrong

You have done wrong."
Fyì-gi
wù
sò̀n-re
màha mu bó.
python-DEF.G1s FOC
poison-DEF.G4 HAB you kill

THE PYTHON's poison kills you.'

In the following example, the wu-marked possessor (the Wara fetish) is explicitely contrasted with the king of Sikasso. They form a set in that both are executing wrongdoers in Sikasso. The implicit member of the possessum set ('people-killing') is of course implied in the clause "you (= the king of Sikasso) are killing people”.

(18) Ká mu ú jwú "é! fânhàfee shuunní sì j̀̀-jà ǹ̀-pyì and you NARR say e! kings two FUT FP-be.able FP-be 'Then you (= the king of Sikasso) said, "E! There cannot be two kings

Sukwol'e mé."Mu na supyì-re kwùù, Wárá-pi sì Sikasso in NEG you PROG people-DEF.G4 kill.IMPFV wara-DEF.G1s ADV.PROG in Sikasso.” You are killing people, yet the Wara (= a type of fetish) is also

supyì-re kwùù. Mu na cáà wárá-pi fòo tàha à wárá-pi people-DEF.G4 kill.IMPFV you PROG FUT Wara-DEF.G1s owner use SCN Wara-DEF killing people. You will sacrifice the Wara owner to the Wara.

sun. Wárá-ni wù supyi-bò-ni li gûu j̀-jyéré. offer.sacrifice Wara-DEF.G1s FOC people-kill-DEF.G3s it POT FP-stop. It is the WARA's killing of people that would stop.' 
It is also possible for the contrasting member of the possessor set to be present in the speech situation rather than mentioned in the discourse. In the following example, the set given in the speech situation is that of all those offering sacrifices on a particular occasion. In most sacrifices, a chicken or goat must be brought by each head of household. He typically says, as he hands the sacrificial animal to the sacrificer, "This is MY chicken," or "Here is MY animal." In lieu of an actual animal, the offering may consist of a sum of money, but even in that case the offerer will say "Here is MY animal." In the following example, the occasion was the inauguration of a new jinn house. Heads of household and various individuals brought chickens to sacrifice. Speaker A was interviewing speaker $\mathrm{K}$ while the ceremony was going on. Speaker $\mathrm{K}$ is a uterine niece of the patriclan that was inaugurating the jinn house. The object of the interview was to find out what role $\mathrm{K}$ played as a uterine niece at the event. K states that she gave money in lieu of an animal. She implicitly contrasts herself with all the other people who offered sacrifices that day.

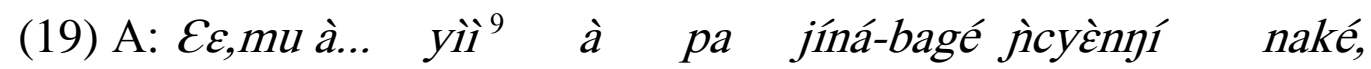
uh you PERF you.PL PERF come jinn-house inauguration onTIME.CLAUSE 'Uh, since you ... you have come to the inauguration of the jinn house,

K: Hmm.

Yes.

A:narafem-báárá na jye nahá la? Jíná-bagé jìcyènní cyàgé e la? narafoo ${ }^{10}$-work PROG be here QUES jinn-house inauguration place in QUES is there any role for a uterine niece? At the inauguration of the jinn house?

$\mathrm{K}$ : Aan.

Yes.

A: $M u$ à pa gé, Jàhá ná jàhá mu à pyi ye? you PERF COme TIME.CLAUSE what and what you PERF do QUES Since you came, what things have you done?
K: Mì̀ à pa maá wyéré
I PERF Come and.NARR money take.out SCN put.down
I came and put down some money,

9 The interviewer (A) is considerably younger than the interviewee (K). He starts to address $\mathrm{K}$ with the singular pronoun $m u$ and then thinks better of it and switches to the plural pronoun yì, which is more respectful. The ... is not an omission, but merely signals the restart. The interviewer switches back to a singular pronoun in line 5 of the example.

Narafoo is the term used for both uterine nephew and uterine niece of a clan. 


\section{A: Hmm.}

Yes.

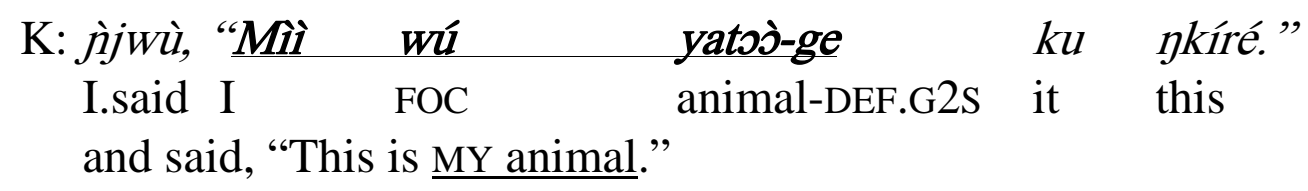

Another speech situation with an obvious contrastive set is any conversation, where the interlocuters form a set (cf. 7c above).

(20) Là màha pi

INDEF HAB them

'Something may be too much fo

\section{Miì wú hákilì-mí}

na, lire na

I FOC mind-DEF.G1s at that PROG

In MY opinion, that's a good thing.'

\section{Non-contrastive examples}

A large number of $w u$-marked genitives $(101,=47.2 \%)$ cannot be shown to be contrastive in the operational sense employed above. This is not surprising in that other focus constructions which may also be interpreted as at least sometimes contrastive and that have been discussed in the literature are also reported to have non-contrastive uses. For focus stress in English, see Lambrecht (1994: 286ff). Unfortunately, Lambrecht does not provide any actual discourse data (there is only one "attested" example in the discussion), let alone any frequencies. Myhill and Xing (1996) show that 51\% (59 of 116) of fronted objects in their corpus of Biblical Hebrew can be shown to be contrastive using their operational definition (1996: 325). In Chinese they investigated four different "patient-fronting" constructions, and they show that contrastive uses account for $15 \%, 32 \%, 22 \%$, and $11 \%$ of the respective constructions (1996: 329). A proportion of $52.8 \%(\mathrm{~N}=113)$ for $w u$-marked genitives in Supyire thus falls in about the same range as object fronting in Biblical Hebrew.

Following are three examples of non-contrastive wu-marked genitives by way of illustration. The first example is from the same interview as example (19) above.

(21) A: Nàhá ná nàhámu rá à pyi $\quad$ a ní Nacíní
what and what you go PERF
'What things did you go do there in Nacin?


Cyire j̀̀cyíi cyì $y \varepsilon$ ?

these these INDEF QUES

What things of this sort?

$\begin{array}{llllll}\text { K: 'Ncyíi mìi } & \text { à } & \text { pyi aní } & \text { nincyiigíi } & \text { ge, } \\ \text { these I PERF do } & \text { there } & \text { first.ones } & \text { REL } \\ \text { The first things I did there, } & & & \end{array}$

A: Aan.

Yes.

K: ceè-ni wà wù kì̀shyàhà mpyi à waha, woman-DEF.G1s INDEF FOC luck PAST PERF be.hard a certain woman's luck was bad,

$u$ gú ràa ntàà $m \varepsilon$.

she POT PROG get.IMPFV NEG

she wasn't getting children.'

The following example is from a folktale.

(22) Nyâ, pi a sà 'Mpi yaha aní ke, well they PERF go Hare leave there TIME.CLAUSE 'Well, when they went and left Hare there,

maá yí jwú 'Mpi á,
and.NARR it say Hare to
they said to Hare,

(Lire tèn'a sùpyíi-bií pì wù kergge ta aní númê.) this time PERF people-DEF.G1P INDEF FOC field find there now (At that time a field of some people was there.)

$\begin{array}{lllllll}p i & a & y i ̀ & j w u ̀ ~ & M p i & a & k e\end{array}$ they PERF it say Hare to TIME.CLAUSE when they said to Hare,

"Bon eq si-shyé-nàmbaabií kà mìpáa pi si-shê-bórigíi bon uh bush-go-men COND come.IMPFV they bush-go-bags "OK, uh, when the farmers are coming and hanging up their 
yùù na duruge...

take.IMPFV PROG raise.IMPFV

farming bags...’

In both of the previous examples the possessor is indefinite, although referential. In the final example, from another interview, it is definite:

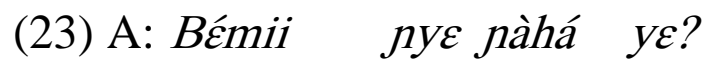 bemii be what QUES 'What are bemii?

D: Nwòhòyyee cyáge, nàmpèyyè-yí tàtè̀̀n-gé. men.old place men.hero.old-DEF.G2P dwelling.place-DEF.G2s The place of the old men, the dwelling place of the heros of old.

Fólófóló wùu tìi-bíi wù tatzèn-ge,

long.ago we fathers-DEF.G1P FOC dwelling.place-DEF.G2s

The dwelling place of our fathers

kuru ku nye bémii.

that it be bemii

of long ago, that is bemii.'

\section{Discussion}

The construal of an entity as an "alternative" is a pragmatic act, whether that entity is referred to in the discourse, inferred from some other entity that is mentioned, or present in the speech situation. Even if there is an overt second genitive, as in the examples in sections 3 and 4, it still must be interpreted as contrastive to the wu-marked genitive. There may be other genitives in the context which are not to be construed as contrastive. The construction of sets, itself a pragmatic act, for both possessors and possessa, is crucial. For instance, in example (11) there are two genitive constructions, with pronominal possessa, which intervene between the two genitive constructions which I take to be contrastive. The possessa of the intervening genitives do not form a set with the possessa of the contrasting genitives, although their possessors are the same. The pragmatic construal of contrast by the hearer crucially depends on the construction of sets. These sets are not marked in any way, but must be inferred.

We may assume that the wu-marked genitive has the effect of triggering an "open presupposed genitive" (MY father implying $x$ 's father) analogous to the "open presupposed proposition" said to be triggered by focal stress in English (SUE hit Bill implying $x$ hit Bill) (Lambrecht 1994: 277ff; cf. Breheny 1998). The 
Supyire hearer is thus cued to be ready for the possibility that the referent of the $\mathrm{x}$ variable may be an something else in the context, and will be ready to draw that contrastive inference in case that "something" is encountered (usually coming in the next clause or two, but sometimes already in working memory from a previous mention). ${ }^{11}$ The evidence reviewed above shows that roughly half the time such an inference will be highly supported by the context. It is interesting that in more than half the cases the construal of contrast is supported by further elements in the context (antonymous possessa or other antonyms outside the genitive constructions themselves or negation), as shown in section 4 .

Almost half the time there is no obvious contrast in the context. These cases will have to be studied further in order to see whether (i) there is contrast, but it is arrived at via inferences which are more subtle than those captured by Myhill and Xing's operationalization of contrast, or (ii) wu-marked genitives encode general focus which is not always contrastive. The latter seems the more likely in view of Lambrecht's claims about English focal stress. In fact, as Myhill and Xing's study hints, and as Lambrecht suggests, it may be the case that no language has a construction which is uniquely devoted to contrastive focus, but that contrast is always only one of the possible interpretations of a given focus construction. In view of this likelihood, the statement in Carlson (1994) quoted in section 1 should be revised by removing the word "contrastive".

It remains to be seen if other subtypes of focus can be operationalized in a fashion similar to the operationalization of contrastive focus. If so, it will be possible to see if $w u$-marked genitives correlate with other types of focus so defined. It seems likely, though, that the very vaguenss of the notion of focus ensures that a construction such as the Supyire wu-marked genitive can be construed contextually in a number of ways. We should not expect a $100 \%$ "coding” relation between such a construction and any particular independently defined type of focus.

As noted above, the other half of this study remains to be done. Ordinary genitives will need to be examined to see how many of them correlate with contrastive focus as operationally defined above. My hypothesis is that a much lower percentage will occur in contexts which explicitly invite a contrastive inference.

\section{Abbreviations}

ADV adversative auxiliary

COND conditional mood auxiliary

11 I assume a relatively small "contrastive space” for the processing of contrast (cf. Breheny 1998). This is the main reason for limiting the search space to 6 clauses in either direction. 


$\begin{array}{ll}\text { DEF } & \text { definite noun suffix (also marks noun class) } \\ \text { DIM } & \text { diminutive noun suffix } \\ \text { FOC } & \text { genitive focus particle } \\ \text { FP } & \text { future tense verb prefix } \\ \text { FUT } & \text { future tense auxiliary } \\ \text { G1S } & \text { gender 1 singular noun suffix } \\ \text { G1P } & \text { gender 1 plural noun suffix } \\ \text { G2S } & \text { gender } 2 \text { singular noun suffix } \\ \text { G2P } & \text { gender 2 plural noun suffix } \\ \text { G3S } & \text { gender } 3 \text { singular noun suffix } \\ \text { G4 } & \text { gender 4 noun suffix } \\ \text { HAB } & \text { habitual tense auxiliary } \\ \text { IMPFV } & \text { imperfective aspect (auxiliary or verb suffix) } \\ \text { INDEF } & \text { indefinite pronoun or determiner } \\ \text { INTR } & \text { intransitive verb prefix } \\ \text { LOC } & \text { locative nominal prefix } \\ \text { NARR } & \text { narrative tense auxiliary } \\ \text { NEG } & \text { negative auxiliary or clause final marker } \\ \text { PERF } & \text { perfect tense-aspect auxiliary } \\ \text { POSS } & \text { possessum pronoun } \\ \text { POT } & \text { potential auxiliary } \\ \text { PROG } & \text { progressive aspect auxiliary } \\ \text { QUES } & \text { clause final question marker } \\ \text { REL } & \text { relative clause marker } \\ \text { SBJCV } & \text { subjunctive mood auxiliary } \\ \text { SCN } & \text { serial verb connective } \\ \text { SEQ } & \text { sequential tense auxiliary } \\ & \end{array}$

\section{$9 \quad$ References}

Breheny, Richard. 1998. Interface economy and focus. In Villy Rouchota and Andreas H. Jucker, eds. Current issues in relevance theory. Amsterdam: Benjamins, pp. 105-139.

Carlson, Robert. 1994. A grammar of Supyire. Berlin: Mouton de Gruyter.

Chafe, Wallace. 1976. Givenness, contrastiveness, definiteness, subjects, topics and point of view. In Charles Li, ed. Subject and topic. New York: Academic Press, pp. 25-56.

Halliday, Michael A. K. 1967. Notes on transitivity and theme in English, part II. Journal of linguistics 3.199-244. 
Lambrecht, Knud. 1994. Information structure and sentence form: topic, focus and the mental representation of discourse referents. Cambridge: Cambridge University Press.

Myhill, John, \& Zhiqun Xing. 1996. Towards an operational definition of discourse contrast. Studies in Language 20.2.303-360. 